URIC ACID.

A RATIONAL TREATMENT FOR ITS ELIMINATION, IN THE LIGHT OF RECENT RESEARCH.

By ROBERT FENNER, L.R.C.P. EdIN,, M.R.C.S. ENG.

THE causes and treatment of those diseases depending upon an excess of uric acid in the blood and its deposition in the tissues of the body have been shrouded for years in mystery and the recorded theories founded on clinical research are fraught with fallacies. As a subject it is of the utmost importance to the practising physician. In few other troubles are his remedies and treatment so impotent. Many have been the theories but the advance in treatment has been practically nil. The main object of all treatment hitherto has been to prevent the accumulation of the salts of uric acid in the system and to favour their excretion, but no attempt has been made to deal with uric acid per se or to prevent the formation of the urates. A great variety of drugs have been exploited and are in daily use to rid the system of their presence after their formation. It is much as if the stable door be shut after the horse has disappeared. With all diffidence $I$ hope, on the basis of recent researches by Minkowski, Kossel, and Schmoll, to prove that there is a substance which, by holding uric acid firmly in solution, prevents its deposition in the tissues in the form of salts; that this substance answers the chemical and physiological tests required; and that its exhibition is clinically successful in those cases which depend upon an excess of uric acid in the blood.

Gout has been generally considered to be an acute arthritis associated with a deposit of crystalline sodium biurate in the joints affected and with a circulation of an excess of urates in the blood. According to the usually accepted theories the excess of uric acid in the blood is due either to $(a)$ increased production or $(b)$ decreased elimination by the kidneys. Garrod adopted the second view. Roberts ${ }^{1}$ gave it as his opinion that the sodium salt present is the quadriurate and if this is in excess or not rapidly eliminated it forms sodium biurate by coming into contact with sodium carbonate, but Fischer conclusively proves that the quadriurates are a mixture of the urates and uric acid in its free state. Murchison ${ }^{2}$ thought that there was excessive formation of uric acid through deficient oxidation of the ingesta owing to functional inactivity of the liver and therefore he considered uric acid a half-way product in the oxidation of albuminous foods. Latham suggested the theory that the increase of uric acid was due to the imperfect metabolism of glycocine in the liver.

Haig ${ }^{3}$ has given us a most interesting and entertaining volume upon uric acid, in which almost all "the ills that flesh is heir to" are stated to be due to some form of uricacid poisoning and these may be divided into two groups: (a) gout and (b) collæmia. He advances the theory that "gout is relieved by solvents, collæmia by retentives. Both are prevented, relieved, or wiped off the record by a uric-acid-free diet. Gout is accompanied by a quick circulation, raised temperature, and a few granules in the blood. Collæmia is accompanied by a slow circulation, subnormal temperature, and many granules in the blood-both are the results of excess of uric acid in the body and that excess is produced by swallowing it in the food." In collæmia he thinks that uric acid is present in the blood as a colloid or gluey material and mechanically blocks the capillaries, causing: " 1 . High blood pressure in the arteries, 2. Increase in the heart's work. 3. Obstruction of the capillaries. 4. Defective combustion." His dietetic treatment is important, as he certainly aims at the reduction in quantity of the uric acid itself, for he only allows his patients those foods which are calculated to sustain life in birds and rodents. One's experience in practice is that patients will not endure a treatment which de. prives them of most of those foods which make ordinary life worth the living, and for whose digestion our organisation has been fully adapted by a beneficent Creator. His theory might hold good in the case of a gouty person in

1 Roberts : On the Chemistry and Therapeutics of Uric Acid, Gravel, and Gout, 1892 .

2 Murchison: Clinical Lectures on Diseases of the Liver, 1877.
3 Haig: Lric Acid as a Factor in the Causation of Disease, 1896. whom it is all-important to restrict the formation of free uric acid but in a healthy person the foods which he forbids are absolutely necessary for sustained and vigorous life, where the ingestion of nucleins is followed by an adequate metabolism. As will presently be proved the uric acid not only becomes perfectly soluble in the blood stream but is maintained in that condition and prevented from being deposited in the tissues by a substance formed at the same time and with which it unites in indissoluble bonds. The important part of Haig's treatment is his clear insistence that it is the irritating presence of uric acid itself in a fibrous tissue, "either in solution or suspension," that is the cause of trouble in his (a) group, and the excess of uric acid in the blood the cause of trouble in his $(b)$ group. In the absence of all scientific proof and the results of research his theory must remain a pious opinion.

Before considering the rôle that uric acid plays in the production of gout it is important to consider its relationship to nutrition. In striking contrast to urea uric acid requires for its solution 16,000 parts of cold water; it is therefore clearly impossible for uric acid to be present in the blood as an acid unless it is in combination with a sub. stance which makes it easily soluble. It is dibasic and has the formula $\mathrm{C}_{5} \mathrm{H}_{4} \mathrm{~N}_{4} \mathrm{O}_{3}$. It forms two classes of salts of which the solubility is almost equally deficient; these are the urates and the biurates: (1) Normal $=2$ atoms of $\mathrm{H}$ replaced by 2 of $\mathrm{Na}=\mathrm{C}_{5} \mathrm{H}_{2} \mathrm{Na}_{2} \mathrm{~N}_{4} \mathrm{O}_{3}=$ urates. (2) Acid $=1$ atom of $\mathrm{H}$ replaced by 1 of $\mathrm{Na}=\mathrm{C}_{5} \mathrm{H}_{3} \mathrm{NaN}_{4} \mathrm{O}_{3}=$ biurates. This latter is the chief constituent of the pinkish so-called "lateritious" deposit. It has been prored that uric acid is not made in the kidness; when these have been removed it continues to be formed and accumulated in the organs, notably in the liver and spleen. In birds, when the liver has been removed, uric acid is scarcely found at all, its place being taken by ammonia and sarcolactic acid, therefore we may assume that uric acid is formed synthetically in this system; of this important fact I shall write later. The conditions which lead to an increased elimination of uric acid in the urine are: 1. An increase of meat diet and a diminution of oxidation which may be brought about by a sedentary life. 2. An increase of white corpuscles in the blood as in leucocythæmia. The leucocytes contain large quantities of nuclein and nuclein yields the xanthin bases to which uric acid is very closely related.

Uric acid had for long been considered a product of the imperfect oxidation of albumin before the formation of urea. Differing from Garrod, Bouchard ${ }^{4}$ suggested that its increase in the serum and in the urine was due to defective oxidation and that this was the pathogeny of gout. But careful chemical research, the discoveries of Fischer ${ }^{2}$ as to the connexion of uric acid with the constituents of the xanthin bases, and the results of phrsiological researches by Kossel $^{6}$ all point to the true origin of uric acid which is totally at variance with the hitherto accepted theories. There are three great classes of proteids: 1 . Albumin, the protoplasm of the living cell containing no phosphorus. 2. The paranucleins, the properties of which are similar to the albuminoid bodies except that they contain a small percentage of phosphorus. They are represented by the yelk of egg and the casein of milk. 3. The nucleins, which constitute the chromatin fibres of the nucleus containing a fair proportion of phosphorus. By the splitting up of the nucleins, as shown by Schmoll, we obtain: (a) albumin (as in protoplasm); and $(b)$ the nucleic acid group: thus

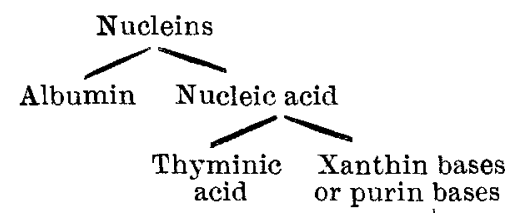

Uric acid.

The nucleins when split up by digestion yield simple albumin and nucleic acid, nucleic acid again yieldirg thyminic acid and the xanthin bases. Fischer ${ }^{7}$ after

4 Bouchard: Lecons sur les Maladies par Ralentissement de la Nutrition, third edition, Paris, 1890.

5 Fischer: Synthesen in der Puringruppe, Berichte der Deutscher Chemischen Gesellschaft, 1899, Band xxxii.

6 Kossel: Ueber Nucleinsaeure, Centralblatt fir die Medicinischen Wissenschaften, 1893. Kossel and Neumann: Uber Nucleirsaeure und Tryminsaeure, Zeitschrift fur Physiologische Chemie, 1896. 
Table I.-Cases of Acute Gout.

\begin{tabular}{|c|c|c|c|c|c|c|}
\hline Case. & Sex. & Age. & Previous history. & Present attack. & Dose. & Remarks. \\
\hline 1 & $\mathbf{M}$. & 46 & $\begin{array}{l}\text { Fad had repeated attacks of acute } \\
\text { gout in foot and knee extending } \\
\text { over the last three years. }\end{array}$ & $\begin{array}{l}\text { Right metacarpo-phalangeal joints } \\
\text { swollen, inflamed, and painful. }\end{array}$ & $\begin{array}{l}4 \text { grains three } \\
\text { times a day. }\end{array}$ & $\begin{array}{l}\text { Cured in five days; previous } \\
\text { attacks usually lasted three } \\
\text { weeks. }\end{array}$ \\
\hline 2 & M. & 42 & $\begin{array}{c}\text { Had had two or three previous } \\
\text { attacks. }\end{array}$ & $\begin{array}{l}\text { Left metacarpo-phalangeal articu- } \\
\text { lations attacked simultaneously. }\end{array}$ & $\begin{array}{l}5 \text { grains three } \\
\text { times a day. }\end{array}$ & $\begin{array}{l}\text { Perfectly well in four days; pre- } \\
\text { vious attacks had lasted from } \\
\text { seven to ten days. }\end{array}$ \\
\hline 3 & M. & 45 & $\begin{array}{l}\text { Subject to acute gouty synovitis } \\
\text { of right knee and pharyngitis. }\end{array}$ & $\begin{array}{l}\text { Painful inflammatory swelling } \\
\text { of knee. }\end{array}$ & $\begin{array}{l}4 \text { grains every } \\
\text { four hours. }\end{array}$ & $\begin{array}{l}\text { The knee was well in five days and } \\
\text { the pharyngitis yielded quiekly } \\
\text { to this treatment. }\end{array}$ \\
\hline 4 & M. & 55 & $\begin{array}{l}\text { Had suffered with various mani- } \\
\text { festations of acute gout at in- } \\
\text { tervals during the past six years. } \\
\text { Had traces of albumin and a } \\
\text { quantity of sugar in urine. }\end{array}$ & $\begin{array}{l}\text { Acute dyspepsia with romiting } \\
\text { and gouty pharyngitis. }\end{array}$ & , & $\begin{array}{l}\text { The acute symptoms had dis- } \\
\text { appeared in five days ; on the } \\
\text { ninth day sugar redueed from } \\
3 \cdot 13 \text { grains per ounce to } 1 \cdot 36 \\
\text { grains per ounce. Has had no } \\
\text { more attacks since taking } 4 \text { grains } \\
\text { of thymrinic acid twice a day. } \\
\text { The sugar has practically dis } \\
\text { appeared. }\end{array}$ \\
\hline 5 & $\mathbf{M}$. & 68 & $\begin{array}{l}\text { Had been subject to gout for } \\
\text { years, having had several attacks } \\
\text { of acute arthritis; isual dura- } \\
\text { tion of attack from three to } \\
\text { four weeks. }\end{array}$ & Acute arthritis of left knee. & $\begin{array}{l}4 \text { grains every } \\
\text { four hours } \\
\text { begu o o } \mathrm{n} \\
\text { second day of } \\
\text { attack. }\end{array}$ & $\begin{array}{l}\text { Cured; inflammation disappeared } \\
\text { in four days. }\end{array}$ \\
\hline 6 & F. & 65 & $\begin{array}{l}\text { Had had several attacks of gout } \\
\text { during the past four years ; } \\
\text { usual duration several weeks. }\end{array}$ & $\begin{array}{c}\text { Severe attack in left foot and } \\
\text { ankle. }\end{array}$ & $\begin{array}{l}4 \text { grains three } \\
\text { times a day } \\
\text { begun on third } \\
\text { day of attack. }\end{array}$ & $\begin{array}{l}\text { Cured on the eighth day of attack; } \\
\text { the patient discontinued thyminic } \\
\text { acid and two months afterwards } \\
\text { had another attack which was } \\
\text { cured as quickly. }\end{array}$ \\
\hline 7 & M. & 54 & $\begin{array}{l}\text { Had repeated attacks of articular } \\
\text { gout lasting from } 10 \text { to } 15 \text { days. }\end{array}$ & Acute arthritis of left ankle. & $\begin{array}{l}4 \text { grains three } \\
\text { times a day. }\end{array}$ & Cured in four days. \\
\hline
\end{tabular}

Table II.-Cases of Chronic Gout.

\begin{tabular}{|c|c|c|c|c|c|}
\hline Case. & Sex. & Age. & History of illness. & Dose. & Remarks. \\
\hline 1 & F. & 70 & $\begin{array}{l}\text { Had suffered for many years with gouty } \\
\text { arthritis of the finger-joints and knees and } \\
\text { latterly with obstinate eczema and bullæ of } \\
\text { the hands. }\end{array}$ & $\begin{array}{l}4 \text { grains three } \\
\text { times a day } \\
\text { after food. }\end{array}$ & $\begin{array}{l}\text { Great improvement after one month's treatment; able to } \\
\text { walk with comfort and to use the hands; at the end of six } \\
\text { weeks the eczema and bullæ had entirely disappeared and } \\
\text { on small doses has kept in good health since. }\end{array}$ \\
\hline 2 & M. & 37 & $\begin{array}{c}\text { Tender swelling in the middle metacarpo- } \\
\text { phalangeal joint of the right hand. }\end{array}$ & $\begin{array}{l}\text { grains three } \\
\text { times a day. }\end{array}$ & $\begin{array}{l}\text { Under prolonged use of thyminic acid the general } \\
\text { condition improved, the swelling diminished, and the } \\
\text { tenderness disappeared. }\end{array}$ \\
\hline 3 & F. & 45 & Swelling and tenderness of the feet. & $"$ & $\begin{array}{l}\text { In one week the condition was so much improved that } \\
\text { she could walk with comfort. }\end{array}$ \\
\hline 4 & F. & 50 & $\begin{array}{l}\text { Stiffness in joints and back ; gouty enlarge- } \\
\text { ment of finger-joints ; excess of uric acid and } \\
\text { urates in urine. }\end{array}$ & $\begin{array}{l}7 \text { grains three } \\
\text { times a day. }\end{array}$ & $\begin{array}{l}\text { After three weeks there was an increased output of uric } \\
\text { acid, the urates disappeared, and the stiffness was much } \\
\text { improved, }\end{array}$ \\
\hline 5 & F. & 69 & $\begin{array}{l}\text { Finger-joints enlarging for some years, at } \\
\text { times becoming inflamed and painful, several } \\
\text { tophi showing; two or three months before } \\
\text { treatment both knees became swollen and } \\
\text { painful. }\end{array}$ & ", & $\begin{array}{l}\text { Well-marked improvement in a fortnight, hands quite } \\
\text { free from pain, knees have recovered shape and mobility, } \\
\text { and all the joints are more flexible. }\end{array}$ \\
\hline 6 & F. & 65 & $\begin{array}{l}\text { Sub-acute arthritis, especially of knees. Acid } \\
\text { dyspepsia and constipation. }\end{array}$ & $\begin{array}{l}4 \text { grains three } \\
\text { times a day. }\end{array}$ & Arthritis improved steadily, also the dyspepsia. \\
\hline 7 & M. & 63 & $\begin{array}{l}\text { Gouty pains in left hand, tophi on little } \\
\text { finger-joints of both hands, eczema on arms } \\
\text { and thighs. }\end{array}$ & $\begin{array}{l}7 \text { grains three } \\
\text { times a day. }\end{array}$ & Improvement rery marked, eczema disappeared. \\
\hline 8 & M. & 35 & $\begin{array}{l}\text { Had suffered with extensive psoriasis of } \\
\text { chest, back, arms, and legs, which had } \\
\text { resisted all treatment for several years. }\end{array}$ & $\begin{array}{l}8 \text { grains three } \\
\text { times a day. }\end{array}$ & $\begin{array}{l}\text { In a fortnight there was marked improvement; in two } \\
\text { months the psoriasis had disappeared but patient being } \\
\text { a careless liver it recurred ; has again almost disappeared } \\
\text { under further treatment by thyminic acid, this time } \\
\text { supplemented by } 14 \text { days' Zittmann's treatment. }\end{array}$ \\
\hline 9 & M. & 57 & $\begin{array}{l}\text { Gouty glycosuria occurring in the course of } \\
\text { an attack of laryngitis; amount of sugar } \\
=8 \text { grains to the ounce. }\end{array}$ & $\begin{array}{l}4 \text { grains three } \\
\text { times a day. }\end{array}$ & $\begin{array}{l}\text { The sugar gradually diminished in quantity and entirely } \\
\text { disappeared in } 14 \text { days; has not recurred. The patient } \\
\text { takes occasional doses of thyminic acid. }\end{array}$ \\
\hline 10 & M. & 46 & $\begin{array}{l}\text { Gouty glycosuria. Sugar }=29 \cdot 14 \text { grains per } \\
\text { ounce. A great gourmand and an alcoholic. }\end{array}$ & $\begin{array}{l}8 \text { grains three } \\
\text { times a day. }\end{array}$ & $\begin{array}{l}\text { In one month the amount of sugar fell to } 8.75 \text { grains per } \\
\text { ounce; in two months to } 3.64 \text { grains per ounce. Now } \\
\text { residing abroad, in good health. }\end{array}$ \\
\hline 11 & F. & 43 & $\begin{array}{l}\text { Suffered from obesity, periodical headaches, } \\
\text { sleeplessness, and dyspepsia. }\end{array}$ & $\begin{array}{l}4 \text { grains three } \\
\text { times a day. }\end{array}$ & $\begin{array}{l}\text { After three months' treatment the patient had lost nine } \\
\text { pounds in weight, the headaches, dyspepsia, and sleep- } \\
\text { lessness had disappeared, and she was able to take } \\
\text { regular walking exercise. She continues to take thyminic } \\
\text { acid (four grains twice a day). }\end{array}$ \\
\hline 12 & M. & 48 & $\begin{array}{l}\text { Gouty laryngitis and eczema of hands. } \\
\text { Tophi present on ears. }\end{array}$ & , & $\begin{array}{l}\text { Cured after two weeks' treatment, but pationt being a } \\
\text { careless liver symptoms again returned but are quickly } \\
\text { disappearing under treatment. }\end{array}$ \\
\hline 13 & M. & 46 & $\begin{array}{l}\text { Had suffered, with repeated attacks of } \\
\text { "gravel" for the past five years. }\end{array}$ & $"$ & $\begin{array}{l}\text { After six weeks' treatment, during which time he was free } \\
\text { from pain, he had an attack of renal colic which ended in } \\
\text { the passing of a small uric acid calculus; since then he } \\
\text { has been perfectly well. }\end{array}$ \\
\hline
\end{tabular}


carefully studying the chemical composition of uric acid and the xanthin bases, conceived them to be derivatives of purin and called them "the purin bodies." The most simple representative of the purin bodies is hypoxanthin, which contains in its molecule one atom of oxygen, and by adding first one atom of oxygen and then two to this substance we obtain successively xanthin and then uric acid, or if the amido group be introduced into the purin nucleus adenin and guanin result, the latter containing one atom of oxygen, the former none. Therefore starting from purin bases we can, by simple chemical changes, obtain uric acid. These purin bodies are found in the organism wherever there are nucleins. The xanthin bases found in the human body are principally adenin and guanin; the bases can thus be combined with thyminic acid to form nucleic acid, as is shown by the following rough scheme : nucleic acid = adenin + guanin + thyminic acid.

Remembering that nucleic acid, by splitting up, yields, nltimately, uric acid and thyminic acid, and basing their theory on the presence of thyminic acid with the intraorganic formation of uric acid, Minkowski ${ }^{8}$ and Kossel advanced the hypothesis that thyminic acid is the substance which combined with uric acid renders the latter soluble and that this combination cannot readily be broken up and together they form a product no longer precipitable either by acids or heavy metals, in fact, uric acid cannct be recovered after it has once combined with thyminic acid without prolonged boiling. Granting that this supposition is correct we can at once form an exact idea of the action of uric acid in the body. As soon as formed uric acid combines with thyminic acid. In this combination it circulates in the blood and this prevents its detection in normal serum. It is excreted by the kidneys, partly in its combined state and partly after the breaking up of this combination. The presence of thyminic acid in health explains why uric acid in the urine is not entirely precipitated by acids. Weintraud ${ }^{10}$ has demonstrated the connexion between nucleic and uric acid by showing that after ingestion of thymus gland extract, which is essentially rich in nucleins, the excretion of uric acid rose from 0.5 gramme to 1.8 grammes and 2 grammes in 24 hours; Hess and Schmoll 11 have shown that the nucleins were the sole origin of uric acid. It was shown that in a healthy person, on a regulated diet, the only way in which the excretion of uric acid could be altered from its normal percentage was by giving foods containing purin bases. The administration of albuminoids brought about no alteration in the quantity excreted. Garrod ${ }^{12}$ established the presence of uric acid in the gouty blood serum and the relation between a gouty attack and deposit of uric acid in the joints. He explained the presence of uric acid in the serum on the hypothesis that it was merely retained there and the deposits were explained in a similar way. There is, however, nothing to indicate any connexion between the excretion of uric acid and its presence in gouty serum. It has been proved that in the healthy physiological state uric acid cannot be found in the blood serum. It is not formed in the kidneys, and before its excretion it has to be carried away in the blood stream. Thus all analyses are tainted with error since we cannot detect uric acid in combination with thyminic acid, and in no other form does it exist in the blood in a physiological state. The presence of uric acid in gouty fluids and tissues may thus be explained by the absence of a proper proportion of thyminic acid combined with it and keeping it in solution. In the normal state uric acid is pro duced by the oxidation of the purin bases; in the gouty state the combination with thyminic acicl does not take place. If thyminic acid be given to gouty people uric acid combines with it, as has been experimentally proved by Schmoll. ${ }^{3}$ It is possible, therefore, that in gout uric acid has an origin other than from the nucleins in which thyminic acid is not at the same time produced.

Ninkowsky has clearly demonstrated the synthetic production of uric acid in birds and Wiener ${ }^{14}$ has established it in animals. The former has proved that all the acids with a chain of three atoms of carbon and two groups of acids can be transformed into uric acid by birds in the presence

8 Minkowski : Die Gicht, 1903. 9 Loc. cit.

10 Weintrand: Berliner Klinische Wochenschrift, 1893.

11 Hess and Schmoll: Archiv fur Experimentelle Pathologie und Pharmakologie. 1896.

12 Garrod: The Nature of Gout, 1861; " Gout," in Reynolds's System Medicine, 1866.

13 Schmoll : Archives Générales de Médecine, No. 39, 1904.

14 Wiener: Beitrage zur Chemischen, Physiologie, und Pathologie, 1902 , Band iv. of urea. This synthetic formation of uric acid is of a minimum quantity and probably always leads to the formation of nucleins, but in the gouty diathesis this synthesis stops at uric acid and it is this amount of acid the presence of which we can prove. In nephritis the presence of uric acid might be due to the fact that the combination of thyminic acid and uric acid is destroyed in the kidneys. Obviously this might also explain its presence in gouty serum but the results of Schmoll's experiments conclusively prove that the excretion of uric acid in gout is enormously increased by the ingestion of thyminic acid, thus refuting the above hypothesis. We may thus express the pathogeny of gout. Uric acid in a gouty organism is formed synthetically, whilst in the normal state it is formed by oxidation; in the latter case thpminic acid, which is always present, combines with uric acid, and it is in this combination that ${ }^{\circ}$ uric acid circulates in the blood. The absence of thyminic acid in gout explains how uric acid is precipitated and found in the serum. Schmoll has made a series of experiments proving the pronounced influence of thyminic acid on the excretion of uric acid in gout; it was increased in every case from 25 to 50 per cent. Another series of experiments on a normally healthy man showed that the ingestion of thyminic acid produced no result.

What, then, are the properties of this substance which holds uric acid in such a grip that, in health, no splitting up can occur and consequently no urates can be deposited in the tissues or joints? A combination so firm that uric acid cannot even be detected in the blood! I have preferred to call this substance "thyminic acid" rather than the "thymic acid" of Schmoll (which might lead to confusion with the products of the herb thyme) or the somewhat clumsily called "nucleotin-phosphoric acid" of Minkowsky and Walker Hall.

Walker Hall, in his valuable handbook on "Purin Bodies," p. 139, says: "An interesting outlook in relation to this question is the action of some bodies which hinder or prevent the precipitation of uric acid and santhin bodies from their solutions. Minkowsky some time since remarked upon this property of nucleotin phosphoric acid and has administered this substance to patients with the view of maintaining the circulating purins in solution and preventing uratic infiltration. At present, however, nucleotin phosphoric acid is not easily obtainable and very few results are recorded." In an interesting discussion on the Chemical Pathology of Gout ${ }^{15}$ A. E. Garrod says: "We do not know in what combination uric acid exists in the blood of the gouty; and I would venture to suggest that this question offers a promising line for investigation--an investigation which is by no means easy at the present day when venesection is no longer in fashion."

Thyminic acid is an amorphous powder, brownish-yellow in colour, soluble in cold water, slightly deliquescent, faintly acid in reaction, and almost tasteless; Minkowski gives its formula as $\mathrm{C}_{30} \mathrm{H}_{46} \mathrm{~N}_{4} \mathrm{O}_{15} .2 \mathrm{P}_{2} \mathrm{O}_{5}$; Kossel as $\mathrm{C}_{16} \mathrm{H}_{25} \mathrm{~N}_{3} \mathrm{P}_{2} \mathrm{O}_{12}$. It has the very interesting property of holding in solution practically its own weight of uric acid at a temperature of $20^{\circ} \mathrm{C}$., while this property of retention is increased by 50 per cent. at the blood temperature of $37^{\circ} \mathrm{C}$. This can easily be confirmed. A slightly alkaline solution of sodium or potassium urate is prepared in a test-tube, care being taken to use only a very small quantity, one-eighth of a grain or even less. In another test-tube a solution is made of a somewhat larger quantity of thyminic acid. Half of the contents of each of these test-tubes is then poured into a third and shaken up together; if the mixture be strongly acidified it will be noticed that the uric acid is held firmly in solution and is not precipitated. If, on the other hand, the test-tube containing the remaining half of the uric acid solution be filled up with water and rendered acid the uric acid will either come down as an amorphous precipitate, or if the solution be weak crystals of uric acid will be slowly formed. According to Kossel, Goto, ${ }^{16}$ and others the "retention property" of thyminic acid is increased when a small quantity of nucleic acid is present. Thyminic acid may be given internally as a powder, in an elixir, or in the form of compressed tablets. Its administration has not, in my experience, been attended by any toxic or untoward symptoms. It is best given with or immediately after meals, in doses of from four to seven grains; in solution it has practically no incompatibles.

During the past 16 months I have had under my care a

5 Brit. Med. Jour.. Sept. 24th, 1904, p. 743.

16 Goto: Zeitschrift für Physiologische Ohemie. 
great number of suitable cases for whom $\mathrm{I}$ have prescribed the thyminic acid prepared by Messrs. Allen and Hanburys, Limited. I usually order this to be taken in doses of from four to eight grains in the tablet form after meals; during its exhibition I have prescribed no other drug and the results have been most gratifying. In acute cases it quickly cuts short the inflammatory condition and leads to rapid convalescence ; in chronic cases prolonged administration of the drug has led to marked improvement in nearly every case. I have been particularly pleased with the results of treatment in cases of gouty glycosuria, gravel, gouty eczema, and obesity. The accompanying cases have been selected at random from my own practice and from those of Dr. A. Butler Harris, Dr. W. M. Abbot Anderson, and Dr. Eugene F. Cronin, to whom I am indebted for having kindly sent me a record of many cases treated by them. I must also acknowledge my indebtedness to $\mathrm{Mr}$. Alfred $\mathrm{C}$. Chapman, F.I.C., F.C S., for much valuable help received in difficult chemical research and experiments.

Buckingham-gate, S.W.

\section{NOTE ON THE RECENT OUTBREAK OF TYPHOID FEVER AT LINCOLN.}

BY E. CECIL CLEMENTS, M.R.C.S. ENG., L.R.C.P. LOND.

THE Lincoln epidemic of typhoid fever is fresh in the memory of most of us and although perhaps sufficient time has not yet elapsed to enable us to form a critical judgment exactly as to what we may learn from it, nevertheless I venture to think that the following observations, based upon 192 cases, even if somewhat crude, will not be valueless.

The Drill Hall temporary hospital was opened on $\mathrm{Feb}$. 9th and $I$ had under my care in the hospital 192 cases. 70 patients were admitted in four days in the majority of them no clinical history could be obtained and it was thus impossible to estimate with any degree of accuracy the stage of the disease upon armission. Of the 192 patients 28 , or 14.5 per cent., died. Of these 28 deaths eight were due to perforation. One case was treated surgically, the result being fttal. Eight deaths were due to hæmorrhage from the bowel, three deaths were caused by meningitis, and four by pulmonary complications. In only four cases did death follow an uncomplicated course. In 28 cases, or 14.5 per cent., relapses occurred; three of these had a second relapse and one had a third relapse. All the patients who experienced relapses are now convalescent. 44 patients presented marked cerebral symptoms; five of these, of whom three died, had undoubted meningitis, One patient was the subject of chronic pulmonary tuberculosis, having a cavity in the right apex. She recovered and the tuberculous condition seems at the present time improving. Four patients were pregnant and none of these aborted or miscarried. 29 cases ran a pyæmic course, characterised by numerous abscesses requiring surgical treatment. In ten cases the normal subsidence of fever was interrupted by a rigor which in most cases was severe. The patient would complain of feeling cold, violent shivering, and the temperature would run up to $103^{\circ}$ or $104^{\circ} \mathrm{F}$, settling down to subnormal within 24 hours and remaining there. The explanation of this would be interesting. Might it be due to separation of sloughs, as in one case where sloughs were recognised in the stool the temperature immediately came down to normal, but no definite rigor was noticeable?

Of the sequelæ observed in this epidemic up to the present time the most important was thrombosis, which occurred in nine cases. Ten patients suffered from suppuration of the ear ; in four of these the previous history showed this affection to be definitely post-typhoidal. In one patient loss of memory and melancholia occurred three weeks after discharge from the hospital. Both these symptoms disappeared after three weeks' rest and sea-air. 'Three cases showed signs of s'ight peripheral neuritis. One patient is still under treatment for choroiditis.

The routine treatment that we adopted can best be considered under the following heads :-

Drugs. - An extensive trial was given to intestinal remedies such as salol, urotropine, Sc. In no instance can I record any definite advantage from their use and in the later cases they were discarded. In cases of threatened cardiac or respiratory failure small doses of tincture of digitalis (from five to ten minims), but if sickness were present liquor strychninæ (from three to five minims), were given. It was found, however, that strychnine was apt to cause hunger. The sedative which after many trials was universally adopted was opium, which was generally supplemented by the application of icebags to the head. The form of opium used was the liquid extract. Morphine and chloral were nothing like so constant in their sedative effects and were after a preliminary trial discarded. Phenacetin was used in ten-grain doses as a sedative and anti. pyretic, either alone or combined with sal volatile or citrate of caffeine. The antipyretic action of this drug was very marked and was always accompanied by profuse diaphoresis. When combined in the above manner no marked depression followed its use and I have often seen it cause a fall of tem. perature (four or five degrees) about four hours after and be followed by a refreshing sleep. Tepid sponging was adopted as a routine practice when the temperature reached $104^{\circ}$. Its result was very varied and sometimes only lasted for an hour. Speaking generally, it was least useful in children and young adults. The highest temperature observed in a patient who recovered was $105.8^{\circ}$. Stimu. lants were used sparingly, only brandy in small doses being administered when necessary.

Purgatives. - Perhaps the mention of this class of drug may cause some surprise, but a very marked feature of the Lincoln epidemic was the absence of diarrhoea. Of 192 patients, only 24 suffered from anything approaching diarrhoea. Of these 24 , in six patients the diarrhœa was profuse, in 11 it was medium, and in seven it was slight. More that 70 per cent. of the patients suffered from parsistent constipation and this was treated by soap-and-water or olive-oil enemata or by the administration of castor oil by the mouth. These measures invariably relieved the symptom in question and in no case did any untoward result follow their use.

Hamostatics. - As 33 cases of bad hæmorrhage occurred with eight deaths one had ample material upon which to estimate the relative value of hæmostatics. Various new drugs, such as adrenalin, were used. These preparations did not give very satisfactory results and were eventually discarded in favour of pilula plumbi cum opio (B.P.).

Dietetics. - The dietetic treatment of typhoid fever is a subject upon which so much has been written that if I had not what I believe to be a fresh experience to record my remarks wou'd have been very brief. It frequently happened that during what was estimated as being the third week of typhoid pyrexia the patient's strength was at the lowest possible ebb. In these cases it was felt that in addition to the use of stimulants, which on account of their tendency to increase the cerebral symptoms had to be used with great caution, some strengthening of the milk diet must be resorted to. In this connexion an extensive trial was first of all made with a number of so-called bland meat proteid. albumose, and peptone preparations. It was found that these were ill borne by the patient and, in the main, were followed by an increase in abdominal pain and distension, in most cases culminating in diarrl œ 1 , sickness, and even an increase in pyrexid. Subsequently a trial was made ot various milk foods. especially of those consisting of either simple milk proteid or foods the essential basis of which was milk and farinaceous material partially or entirely converted by the action of a ferment into a soluble form. My experience with these latter foods was that they were of distinct value after the temperature had been normal for from six to eight days. I made several attempts to use then at an earlier date during the continuanc. of slight pyrexia but invariably found that they caused abdominal distension and discomfort, and in two cases definite increase of pyresia. I al:o determined to give sanatogen a trial. It was given in two teaspoonful doses three or four times a day and was added to the milk according to the directions s.upplied. The cases in which it was at first used may le divided into three classes; first, those whose temperature had been normal for a few days before the treatment was started; secondly, those patients who still had a continued evening pyrexia ranging from $100^{\circ}$ to $101^{\circ}$; and thirdly, those in the height of pyrexia. Owing to the extreme difficulty of obtaining accurate clinical histories it is impossible to say at exactly what period of the disease this second class was but apparently it ought to have been convalescence but for the severe asthenia. In the first class 